\title{
The pH-dependent rearrangements of formyltetrahydrofolates and their nutritional implications
}

\author{
By J. R. G. BEAVON AND J. A. BLAIR \\ The Department of Chemistry, The University of Aston, \\ Gosta Green, Birmingham $B_{4}{ }_{7} E T$ \\ (Received I8 December 1971 - Accepted 20 May 1972)
}

\begin{abstract}
I. The rates of hydrolysis of 5,10-methenyltetrahydrofolic acid and of cyclization of roformyl- and 5 -formyltetrahydrofolic acids have been studied in vitro.

2. Io-Formyl- and 5-formyltetrahydrofolate cyclized below $\mathrm{pH}_{4}$, ro-formyltctrahydrofolate being more rapid; the rates of cyclization for these compounds were not concentrationdependent. 5, IO-Methenyltetrahydrofolate was stable below pH 4 ; above this the rate of hydrolysis depended on $\mathrm{pH}$, naturc of buffer and substrate concentration.

3. The relevance of the results to animal and human nutrition is discussed.
\end{abstract}

The pH-dependent equilibria between 5-formyltetrahydrofolic acid (5 $\mathrm{CHO}-$ THF), IO-formyltetrahydrofolic acid ( $10 \mathrm{CHO}-\mathrm{THF}$ ), and 5, I0-methenyltetrahydrofolic acid $(5,10 \mathrm{CH}-\mathrm{THF})$ are shown in Fig. $\mathrm{I}$. The rates of attainment of these equilibria have not been worked out, but are of importance in animal feeding experiments and in dietary studies, since the folate compound ingested may often not be that which is eventually absorbed.

In the synthesis of 5 CHO-THF (Roth, Hultquist, Fahrenbach, Cosulich, Broquist, Brockman, Smith, Parker, Stokstad \& Jukes, I952) the equilibrium

$$
\text { Io } \mathrm{CHO}-\mathrm{THF}+\mathrm{H}^{+} \leftrightharpoons 5,10 \mathrm{CH}-\mathrm{THF}+\mathrm{H}_{2} \mathrm{O}
$$

was allowed $3 \mathrm{~d}$ for completion at $\mathrm{pH}$ o. Graphical results for the cyclization of $5 \mathrm{CHO}$ - THF and $10 \mathrm{CHO}-\mathrm{THF}$ in $0.25 \mathrm{~m}$ hydrochloric acid have been published (Rabinowitz, I960), together with studies on the hydrolysis of 5 , Io $\mathrm{CH}=\mathrm{THF}$, the rate of which is dependent on the nature of the buffer present. The mechanism has been studied (Robinson \& Jencks, $1967 a, b$ ) and the equilibrium constants for the cyclization of 5 CHO-THF and ro CHO-THF have been determined (Kay, Osborn, Hatefi \& Huennekens, 1960).

The in vitro work reported here establishes the reaction half-times for the equilibria in Fig. $\mathrm{I}$ at $\mathrm{pH}$ values likely to be met in the alimentary tract.

\section{EXPERIMENTAL}

\section{Materials and methods}

Chemicals. Calcium leucovorin (providing $5 \mathrm{CHO}$-THF) was a gift from Lederle Laboratories Inc., Pearl River, New York; 2-mercaptoethanol was obtained from Koch-Light Laboratories Ltd, Colnbrook, Bucks.; 5, I0 CH=THF was made by the method of Roth et al. (1952); Io CHO-THF was made by reduction with hydrogen 
<smiles>NCC1CNc2nc(N)[nH]c(=O)c2N1C=O</smiles>

$5 \mathrm{CHO}-\mathrm{THF}$

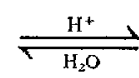

Elevated temperature<smiles>[R]N(C)CC1CNc2nc(N)[nH]c(=O)c2[N+]1=C</smiles>

$5,10 \mathrm{CH}=\mathrm{THF}$

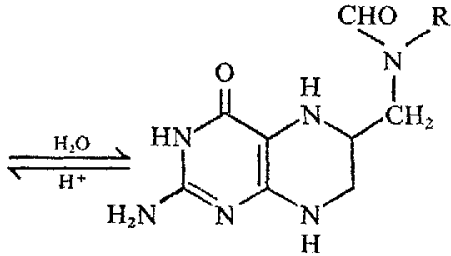

10 CHO-THF<smiles>[R]c1ccc(C(=O)C(CCC(=O)O)C(=O)O)cc1</smiles>

Fig. I. pH-dependent equilibria between 5 -formyltetrahydrofolate (5 $\mathrm{CHO}$-THF), ro-formyltetrahydrofolate (to CHO-THF) and $5,10-$ methenyltetrahydrofolate $(5,10 \mathrm{CH}=\mathrm{THF})$.

using platinum as catalyst, in glacial acetic acid of ro-formylfolic acid prepared by the method of Blakley (1959).

Spectrophometric measurement. $5,10 \mathrm{CH}=\mathrm{THF}$ has a characteristic absorption peak at $355 \mathrm{~nm}$, not possessed by any other tetrahydrofolate. All the reactions were followed by observation of the appearance or disappearance of this peak using a Hilger \& Watts Uvispek spectrophotometer at $25^{\circ}$.

\section{In vitro studies}

Cyclization of 5 CHO-THF to $5,10 \mathrm{CH}=\mathrm{THF}$. The substrate solution was aqueous calcium leucovorin $(0.4 \mathrm{mg} / \mathrm{ml}$ as free acid). Each cuvette $(\mathrm{I} \mathrm{cm}$ path length) contained hydrochloric acid $(2 \mathrm{ml})$ at the required $\mathrm{pH}$, toluene $(0.2 \mathrm{ml})$, and either water (100 $\mu$ l, reference) or substrate solution ( $100 \mu l)$. The effect of dilution was studied using a $4 \mathrm{~cm}$ light path cuvette containing hydrochloric acid $(8 \mathrm{ml})$, toluene ( $2 \mathrm{ml})$ and either water (IOO $\mu \mathrm{l})$ or substrate solution (IO० $\mu \mathrm{l})$.

Cyclization of 1o CHO-THF to 5, 10 CH=THF. The substrate solution was Io CHO-THF $(0.4 \mathrm{mg} / \mathrm{ml})$ in $0.01 \%(\mathrm{v} / \mathrm{v})$ aqueous ammonium hydroxide containing 2-mercaptoethanol $(20 \mu \mathrm{l} / \mathrm{ml})$. Each cuvette (I cm light path) contained hydrochloric acid $(2 \mathrm{ml})$, 2-mercaptoethanol $(20 \mu \mathrm{l})$, toluene $(0.2 \mathrm{ml})$, and either $0.01 \%(\mathrm{v} / \mathrm{v})$ aqueous ammonium hydroxide (100 $\mu \mathrm{l}$, reference) or substrate solution (roo $\mu 1$ ). 2-Merceptoethanol was included to prevent oxidation of ro CHO--THF to folic acid or Io-formylfolic acid, both of which interfere $\left(\lambda_{\max }\right.$ at $\mathrm{pH} 7,346$ and $348 \mathrm{~nm}$ respectively (Blakley, I969)).

Hydrolysis of 5, 10 CH=THF to 1o CHO-THF. The substrate solution was 5, IO $\mathrm{CH}=$ THF $(0.4 \mathrm{mg} / \mathrm{ml})$ dissolved in hydrochloric acid $(\mathrm{pH} 2)$. Each cuvette ( $\mathrm{cm}$ light path) contained buffer (acetate or phosphate, $2 \mathrm{ml}$ ), 2-mercaptoethanol $(20 \mu \mathrm{l})$, toluene $(0.2 \mathrm{ml})$, and either hydrochloric acid $(\mathrm{pH} 2$, I00 $\mu \mathrm{l}$, reference) or substrate solution (100 $\mu \mathrm{l})$. The $\mathrm{pH}$ of the buffers used was unaffected by $100 \mu \mathrm{l}$ of the acid. Experiments were also done in bicarbonate buffer since this is the predominant buffer ion in the jejunum. Since the buffer capacity is small, it was necessary to use a substrate solution of $5, \mathrm{IO} \mathrm{CH}=\mathrm{THF}(0.04$ or $0.4 \mathrm{mg} / \mathrm{ml})$ in $\mathrm{pH}_{4}$ hydro- 
Vol. 28

Table 1. Cyclization of 5-formyltetrahydrofolate to 5,10-methenyl-tetrahydrofolate in hydrochloric acid at $25^{\circ}$ ( $\mathrm{t}$ is the reaction half-time in min)

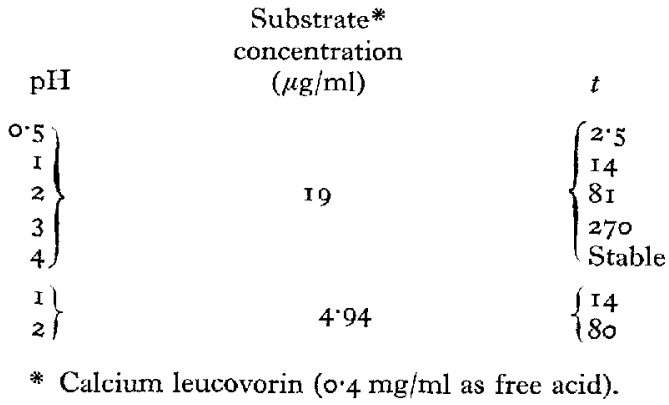

Table 2. Cyclization of no-formyltetrahydrofolate (10 CHO-THF) to 5, 10-methenyltetrahydrofolate in hydrochloric acid at $25^{\circ}$. (Substrate* concentration $19 \mathrm{\mu g} / \mathrm{ml}$; $\mathrm{t}$ is the reaction half-time in $\mathrm{min}$ )

$\begin{array}{cc}\mathrm{pH} & t \\ \mathbf{I} & \mathrm{T} \cdot 0 \\ 2 & 8 \cdot 5 \\ 3 & 35 \\ 4 & \text { Stable }\end{array}$

* ro CHO-THF $(0.4 \mathrm{mg} / \mathrm{ml})$ in $0.01 \%(\mathrm{v} / \mathrm{v})$ aqueous ammonium hydroxide containing 2-mercaptocthanol $(2 \circ \mu \mathrm{l} / \mathrm{ml})$.

chloric acid, and $4 \mathrm{~cm}$ light path cuvettes. Each cuvette contained buffer $(8 \mathrm{ml})$, toluene ( $2 \mathrm{ml}), 2$-mercaptoethanol $(80 \mu \mathrm{l})$, and either hydrochloric acid ( $\mathrm{pH}_{4}, 100 \mu \mathrm{l}$, reference) or substrate solution ( $100 \mu \mathrm{l})$.

\section{RESULT'S AND DISCUSSION}

The results are given in Tables $\mathrm{I}-3$.

The fate of each of the three compounds within the alimentary tract will be considered separately. Normal gastric $\mathrm{pH}$ is about 4 in the rat (Gordon, 1968) and the gastric evacuation time $\mathrm{I}$ h (Ely \& Ross, 1947). In man, the gastric $\mathrm{pH}$ resting value appears to be between $\mathrm{I}$ and 2 , rising to 5 by neutralization with food, after a meal, then returning to between $\mathrm{pH}$ I and 2 (James \& Pickering, I949). Thirty minutes after a meal of steak the initial gastric $\mathrm{pH}$ of 5 in normal subjects has returned to between 2.55 and $3.35 ; 90$ min later to between ${ }_{1} \cdot 8$ and 2.3 (Fordtran \& Lochlear, I966). These are average values; the antral contents are generally more acid. Thirty minutes after a meal of meat the antral chyme $\mathrm{pH}$ lies between $2 \cdot 5$ and $3 \cdot 4$ and $\mathrm{I} h$ later the $\mathrm{pH}$ has reached a steady value of just under 2 (Davenport, 1971). The vigorous movements of a full stomach ensure that all food comes into contact with this fluid at the periphery of the bolus. Freshly secreted gastric juice before being diluted with food has a $\mathrm{pH}$ of about $\mathrm{I}$. Gast ic evacuation time varies with the meal composition; a light liquid meal having a half emptying time of about $40 \mathrm{~min}$, a liquid meal of higher osmotic pressure a half emptying time of $60 \mathrm{~min}$ and meals containing protein 
Table 3. Hydrolysis of 5, 10-methenyltetrahydrofolate $(5, \mathrm{IO} C H=T H F)$ to ro-formyltetrahydrofolate in the three buffers at $25^{\circ}(\mathrm{t}$ is the reaction half-time in min)

\begin{tabular}{|c|c|c|c|}
\hline Buffer & $\mathrm{pH}$ & $\begin{array}{l}\text { Substrate* } \\
\text { concentration } \\
\quad(\mu \mathrm{g} / \mathrm{ml})\end{array}$ & $t$ \\
\hline Acetate, $O \cdot I M$ & $\left.\begin{array}{l}4 \\
5\end{array}\right\}$ & I9 & $\left\{\begin{array}{l}\text { Stable } \\
\text { Stable }\end{array}\right.$ \\
\hline Phosphate, O. I M & $\left.\begin{array}{l}6 \\
7\end{array}\right\}$ & I9 & $\left\{\begin{array}{l}\mathrm{I} 4 \\
\mathrm{IO}\end{array}\right.$ \\
\hline Bicarbonate: & $\left.\begin{array}{l}6 \\
7 \\
6 \\
7\end{array}\right\}$ & $\begin{array}{l}4.9 \\
0.49\end{array}$ & $\begin{array}{l}\left\{\begin{array}{r}\text { I } 16 \\
80\end{array}\right. \\
\left\{\begin{array}{r}22 \\
2\end{array}\right.\end{array}$ \\
\hline
\end{tabular}

or fat may persist in the stomach from 4 to $6 \mathrm{~h}$ with an extreme of $20 \mathrm{~h}$ (Davenport, 197x). The temperature of the empty stomach is about $37^{\circ}$ but varies with the meal taken. A $250 \mathrm{ml}$ liquid meal taken at $57^{\circ}$ raises the gastric temperature to $44^{\circ}$ within $2 \mathrm{~min}$ from which it reverts to normal in $18 \mathrm{~min}$ (Davenport, 1971). A meal of icecream reduces gastric temperature to $22^{\circ}$ (Davenport, 1971 ). The experimental results for cyclization are quoted for a temperature of $25^{\circ}$; the higher gastric temperatures would reduce the half-life for cyclization. Normal jejunal $\mathrm{pH}$ in both rat and man is about 6.5 (Gordon, I968; Benn, Swan, Cooke, Blair, Matty \& Smith, 1971).

${ }_{5}$ CHO-THF. At $\mathrm{pH} 4$, or higher, ${ }_{5} \mathrm{CHO}-\mathrm{THF}$ did not cyclizc (Table $\mathrm{I}$ ); in the rat it is therefore unlikely that significant amounts of $5,10 \mathrm{CH}=\mathrm{THF}$ would be produced. Analysis of faecal radioactivity after administration of $\left[2-{ }^{14} \mathrm{C}\right]-5 \mathrm{CHO}-$ THF (Beavon and Blair, unpublished) showed that $95 \%$ of the excreted radioactivity was 5 CHO-THF. In man, gastric $\mathrm{pH}$ is low enough for possibly all of the dose to cyclize if given on an empty stomach. If taken in food, the amount of cyclization would vary with the $\mathrm{pH}$ and the time it remains in the stomach: where stomach acidity is low, half emptying time short, stomach temperature low and gastric mixing poor, most 5 CHO-THF would be uncyclized and pass to the jejunum unchanged. Where stomach acidity is high, half emptying time long, stomach temperature high and gastric mixing good, a proportion of $5 \mathrm{CHO}-\mathrm{THF}$ would be cyclized and a mixture of $5 \mathrm{CHO}-\mathrm{THF}$ and 5 , ro $\mathrm{CH}=\mathrm{THF}$ enter the jejunum.

Io $\mathrm{CHO}-\mathrm{THF}$. At $\mathrm{pH} 4$, Io CHO-THF did not cyclize (Table 2), thus in the rat stomach, which has a pH of 4 , 10 CHO-THF would not cyclize, and would be absorbed as such. In man, in an empty stomach, cyclization would be much quicker than that of ${ }_{5} \mathrm{CHO}-\mathrm{THF}$, giving $5, \mathrm{rO} \mathrm{CH}=\mathrm{THF}$ almost entirely, this then being hydrolysed to to CHO-THF and possibly some 5 CHO-THF in the jejunum. If taken in food the proportion cyclized would vary with gastric retention time, gastric mixing, stomach temperature and $\mathrm{pH}$ but would always be very much greater than that of 5 CHO-THF.

5, $10 \mathrm{CH}=\mathrm{THF}$. At $\mathrm{pH} 5$ or lower, $5, \mathrm{IO} \mathrm{CH}=\mathrm{THF}$ was stable to hydrolysis (Table 3 ). It will thus pass through the stomach unchanged, but be hydrolysed in the 
jejunum. The extent of this is difficult to predict, since reaction rate was dependent both on concentration and on the type of buffer, in agreement with previous studies (Rabinowitz, 1960). Since bicarbonate is probably the chief buffering ion in the jejunum, the discussion refers to the values for that buffer. It is likely that a large proportion will be hydrolysed to Io CHO-THF; some 5 CHO-THF could also be formed. 5, ro $\mathrm{CH}=\mathrm{THF}$ is strongly adsorbed on to cellulose powder, and possibly therefore on to fibrous dietary constituents (Luther, Santini, Brewster, Perez-Santiago \& Butterworth 1965 ; Beavon and Blair, unpublished). $5,10 \mathrm{CH}=\mathrm{THF}$ adsorbed on to Florisil at $\mathrm{pH}$ i is eluted by $\mathrm{pH} 9$ ammonium hydroxide partly as $5, \mathrm{ro} \mathrm{CH}=\mathrm{THF}$ and partly as 5 CHO-THF rather than the expected ro CHO-THF. Analysis of faecal radioactivity from rats given $\left[2-{ }^{14} \mathrm{C}\right]-5,10 \mathrm{CH}=\mathrm{THF}$ showed four components; three were identified as 5 , 10 $\mathrm{CH}=\mathrm{THF}(c .10 \%), 5 \mathrm{CHO}-\mathrm{THF}(c .10 \%)$ and 10formylfolic acid ( $10 \mathrm{CHO}-\mathrm{F} ; c .70 \%$ ), the latter probably arising from oxidation of 1o CHO-THF (Beavon and Blair, unpublished). The jejunum is normally anaerobic, so that io CHO-THF would escape oxidation.

\section{Conclusion}

Formylfolates constitute a significant proportion of folates in food. On microbiological assay with. Pediococcus cerevisiae, formylfolates accounted for $12 \%$ of total folate in asparagus, $44 \%$ in chicken liver, and $59 \%$ in red kidney beans (Santini, Brewster \& Butterworth, 1964). Perry (1971) found $30 \%$ of total folate to have $P$. cerevisiae activity in a hospital diet. Distribution of activity between $5, \mathrm{IO} \mathrm{CH}=\mathrm{THF}$, Io $\mathrm{CHO}-\mathrm{THF}$ and ${ }_{5} \mathrm{CHO}-\mathrm{THF}$ is unclear, partly because of the ease of interconversion, and partly because until the advent of these compounds labelled with ${ }^{14} \mathrm{C}$ (Beavon \& Blair, 1971) specific analysis proved difficult. 10 $\mathrm{CHO}-\mathrm{F}$ has been found in foods (Butterworth, Santini \& Frommeyer, 1963; Lewis, I967), and may be derived from to $\mathrm{CHO}-\mathrm{THF}$ oxidation. The $\mathrm{pH}$-dependent rearrangements have also to be borne in mind when performing administration experiments with formylfolates in metabolic studies.

We are grateful to the Wellcome Trust for financial support.

\section{REFERENCES}

Beavon, J. R. G. \& Blair, J. A. (1971). Analyt. Biochem. 44, 335.

Benn, A., Swan, C. H. J., Cooke, W. T., Blair, J. A., Matty, A. J. \& Smith, M. E. (r97 I). Br. med. f. i, I 48 .

Blakley, R. L. (1959). Biochem. F. 72, 707.

Blakley, R. L. (1969). The Biochemistry of Folic Acid and Related Pteridines p. 92. Amsterdam and London: North-Holland.

Butterworth, C. E. Jr, Santini, R. \& Frommeyer, W. B. Jr (1963). F. clin. Invest. 42, 1929.

Davenport, H. W. (1971). Physiology of the Digestive Tract Ch. I3, p. r63. Chicago: Year Book Medical Publishers L.td.

Ely, J. O. \& Ross, M. H. (r947). In Neutron Irradiation Effects in Animals p. 142 [E. McDonald, editor]. Baltimore: Williams and Wilkins Co.

Fordtran, J. S. \& Lochlear, T. W. (r966). Am. F. dig. Dis. 11, 503.

Gordon, H. A. (1968). In The Germ-free Animal in Research, p. I27 [M. E. Coates, editor]. New York: Academic Press.

James, A. H. \& Pickering, G. W. (1949). Clin. Sci. 8, 18r. 
Kay, L. D., Osborn, M. J., Hatefi, Y. \& Huennekens, F. M. (1960). F. biol. Chem. 235, 195.

Lewis, D. T. (1967). Some Current Problems in Food Analysis. Chemistry, Medicine and Nutrition Symposium, Bristol, r966. p. 77. London: The Royal Institute of Chemistry.

Luther, L., Santini, R., Brewster, C., Perez-Santiago, E. \& Butterworth, C. E. Jr (1965). Alabama F. med. Sci, 2, 390.

Perry, J. (1971). Br. F. Haemat. 21, 435.

Rabinowitz, J. C. (1960). In The Enzymes Vol. 2, and ed., p. I85 [P. D. Boyer, H. Lardy and K. Myrbäck, editors]. New York: Academic Press.

Robinson, D. R. \& Jencks, W. P. (rg67a). F. Am. chem. Soc. 89, 7o88.

Robinson, D. R. \& Jencks, W. P. (1 967b). F. Am. chem. Soc. 89, 7098.

Roth, B., Hultquist, M. E., Fahrenbach, M. J., Cosulich, D. B., Broquist, H. P., Brockman, J. A. Jr, Smith, J. M. Jr, Parker, R. P., Stokstad, E. L. R. \& Jukes, T. H. (1952). F. Am. chem. Soc. 74, 3247.

Santini, R., Brewster, C. \& Butterworth, C. E. Jr (1964). Am. f. clin. Nutr. 14, 205. 